\title{
Current status of Early Warning Systems for severe environmental threats in the Polish Na- tional Meteorological Service
}

\author{
Rafał Bąkowski, Jerzy Achimowicz, Andrzej Mazur \\ Institute of Meteorology and Water Management - National Research Institute, Podleśna Street 61, 01-673 Warszawa \\ Poland,e-mail:rafal.bakowski@imgw.pl,jerzy.achimowicz@imgw.pl,andrzej.mazur@imgw.pl
}

\begin{abstract}
The current state of the art and dedicated applications in Early Warning Systems (EWS) of hydrological and meteorological threats are presented herein. Special emphasis is placed on systems based on the post-processing of deterministic numerical weather forecasts in the real-time mode. The importance of climate and weather forecasting models in providing warnings against slow and rapid onset rates e.g. drought and dispersion of atmospheric pollutants respectively, is discussed. It is strongly suggested that there is a need for systems, corresponding to crisis situations in the field of environmental hazards and/or human activities in general, that would be able to provide support and information about further possible scenarios with a projected state of both the environment and the possibility of the negative impact of various factors on the population (human communities). Since there are highly developed plans for the construction of a nuclear power plant in Poland, there is an urgent need to prepare adequate tools that will help avoid crisis situations, or at least to minimize their negative effects. The Early Warning System should be considered one such tool, to be used not only for its economic benefits, but also for pro-social areas of services responsible for the appropriate reaction to crisis events.
\end{abstract}

Keywords: Early Warning System, hazards, incidents, warning, weather forecasts

Submitted 23 May 2014, revised 9 January 2015, accepted 9 January 2015

\section{Definition of Early Warning System.}

An Early Warning System (EWS) provides the necessary warning information about potentially dangerous events. This information is essential for the reduction or total avoidance of risk brought about by the occurrence of hazards. Early warning is also understood as the process of generation - by relevant bodies/organizations - of the information necessary for the decrease or total reduction of the possible consequences of severe events (cf. Lowe et al. 2011). It is assumed this reduction/elimination will allow the initiation of appropriate countermeasures against hazard(s) and their consequences. Both terms are used in many fields of human activities, such as health services, economic processes or in meteorology and hydrology when dealing with severe weather phenomena (see e.g. Basher 2006).

\section{Importance of numerical weather forecasting - from forecast to warning}

As far as meteorology and climatology is concerned, the crucial role in EWS is usually played by numerical models, which allow for the forecasting of dangerous threats. One example of their application is in expert sys- tems that provide support in the process of the generation of meteorological warnings.

Recently, as the consequence of IMWM-NRI membership of the COSMO consortium, the mesoscale/local numerical meteorological model COSMO (Consortium for Small Scale Modeling) has been used in an operational mode at the IMWM-NRI Headquarters in Warsaw (Schaettler et al., 2009; Schaettler 2009). This non-hydrostatic mesoscale meteorological model - primarily designed and implemented by the German National Weather Service (Deutscher WetterDienst - DWD) - was implemented operationally at IMWM-NRI in 2001 (operational setup is shown in Fig. 1).

Currently four operational model runs at $7 \mathrm{~km}$ horizontal resolution grid are performed for 00, 06, 12 and 18 UTC hours. The initial data are generated at DWD as an output from the global earth atmosphere model (Global Modell Ersatz - GME) and provided by GTS (Global Telecommunication System) from an Offenbach network node. The numerical weather forecasts consist of many gridded fields of meteorological variables, such as atmospheric pressure, precipitation intensity, cloud cover, air temperature, synoptic maps at 300 and $850 \mathrm{hPa}$ pressure levels, as well as many others. 


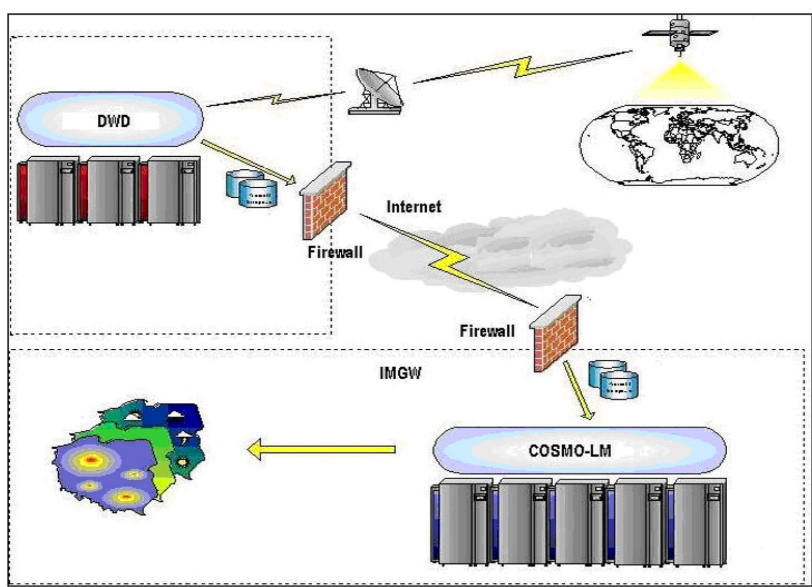

Fig. 1. Operational configuration of numerical weather forecasting at IMWM-NRI

Based on these forecast fields in the process of consecutive numerical processing (called post-processing) fields and maps of other non-standard indices are generated, which can serve, for example, as a basis for evaluation of the probability of severe convection type phenomena (such as storms, wind gusts or intensive rainfall). Using these probabilities of an event, a human operator (forecaster) can make the decision to issue (generate) a warning message of severe weather occurrence. This computer decision support system based on the expert system was operationally implemented in IMWM-NRI in early 2012. The system was the product of the research and development project entitled The climate change effects on environment, economy and society, Contract POIG.01.03.0114-011/08-00, funded partially by EU Operational Program "Innovative Economy" (Mazur et al. 2012a, b).

The operator of the system can aggregate all risk indexes (examples of forecasts of indexes shown in Fig. 2)

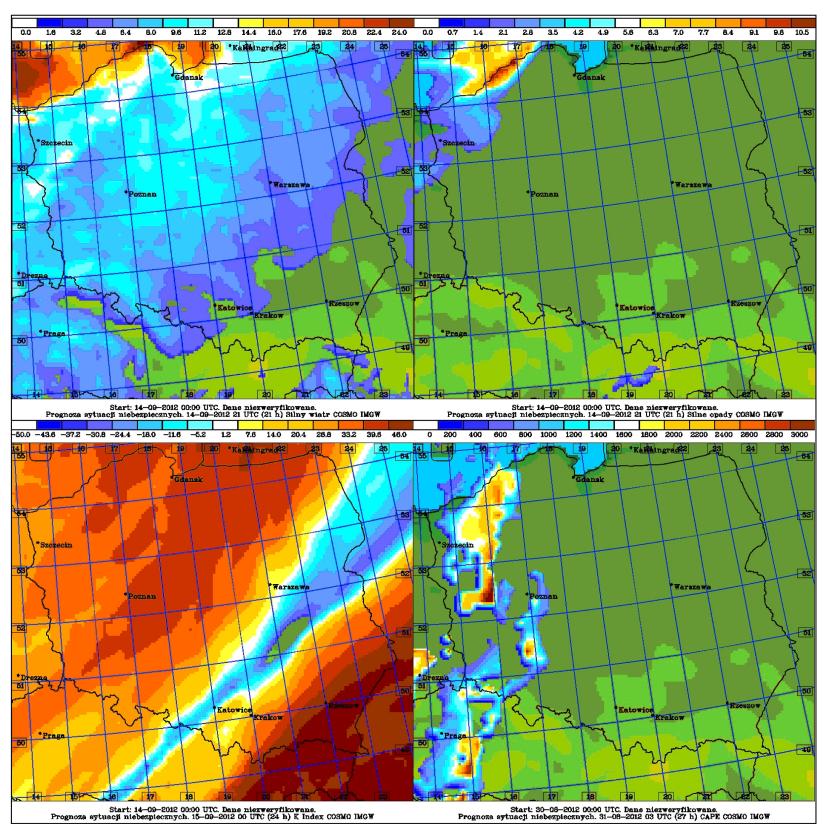

Fig. 2. Examples of severe weather phenomena emergency forecasts

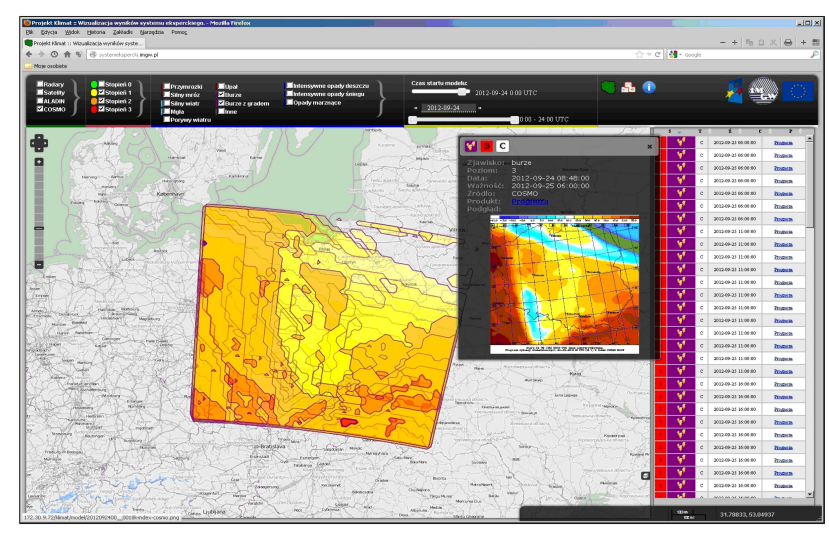

Fig. 3 Expert system interface to assist a human operator in the issuing of a meteorological warning (see http://systemekspercki. imgw.ad; link restricted to IMWM-NRI domain only)

in a single graphical user interface (GUI) where data from numerical forecasts can be displayed together with remote meteorological data (e.g. radars) in real-time, so the warnings can be assigned to a relevant geographical areas of occurrence (see Fig. 3 for an example of the GUI screen).

\section{Transport related hazards (road icing, fog, inten- sive rainfall, poor visibility)}

Since 2005 another specialized system, SOMD (System Osłony Meteorologicznej Dróg - Meteorological Road Protection System), has been operationally implemented at IMWM-NRI. In the design phase the climatological analysis of selected regions was performed, followed by the choice of adequate forecast methodology (Flerchinger, Saxton 1995; Raatz 1995) and design of the visual user interface. The SOMD system is updated online with the current status of the roads from a specialized automatic measurement network and is linked to a telecommunication system dedicated to the dissemination of weather warnings and their delivery to end-user clients, for example road maintenance services. The SOMD system generates selected fields of meteorological variables, such as air temperature or precipitation type and intensity, from deterministic forecasts of the mesoscale numerical COSMO model and an output from the road surface temperature model SHAW(rt) (Flerchinger, Saxton 1995) and the visibility model FOGMOD (Mazur 2004, 2008; Wantuch 2005).

The road surface temperature model is initialized by common forecast fields from the COSMO model, including the type and intensity of precipitation. A core output of this system is a forecast of road surface temperature which - combined with the precipitation data from the COSMO model - results in the forecast of road icing if a rainfall is accompanied by a sub-zero road surface temperature. In turn, the FOGMOD model predicts the type 
of precipitation and warns if there is a high probability of freezing rain. It also groups the visibility into several classes corresponding to 50-meter intervals from zero to a thousand meters visibility. The road state forecasting system consists of an icing probability forecasting model, visibility, precipitation and, additionally, surface and air temperature modules, together with the option for a descriptive type warning and a communication subsystem. Forecasts are generated for a time horizon requested by the end user and can be distributed 4 times per day, and provide the relevant time for initiation of adequate preventive actions and the spare time for its planning. The special module was developed for short term forecasting (i.e. nowcasting) in cases of rapid changes in weather conditions. The system has an open architecture, allowing for the adaptation of system functionalities for road users and road services correspondingly. The system may be used for:

- initiation of preventive actions (road salt spreading);

- fast reaction of road services in the form of road closures at selected locations, together with warning sign generation;

- dissemination of road status information to appropriate web pages;

- planning of adequate resources (material and human) for the protection of transport services;

- adjusting of regional services' availability to current needs that result in the cost reduction of road protection activities, especially during the winter period.

The overall impact of the system implementations results in an increase of road transport safety and efficiency.

It should be stated that the basic space resolution of the COSMO model and, hence, SOMD, is equal to $7 \mathrm{~km}$. Since some of the meteorological elements related to the question of road protection have a local character (e.g. rain or visibility) it should be explained that SOMD connects more general data with local conditions, using actual (ar- chive) values from road measuring stations to "learn" or to improve results via MOS (Model Output Statistics) techniques, eventually producing a site-specific forecast.

\section{Atmospheric pollution transport forecast and diag- nostic approach case studies}

An operational model (Regional Model for Atmospheric Transport of Air Pollutants - REMOTA) for simulating atmospheric transport and deposition of selected pollutants has been developed, implemented and tested at IMWM (Mazur 2004, 2008). This model is, first of all, dedicated to prognostic applications. However, in cases of emergency, such as nuclear accidents or volcano eruptions, it can be run ad hoc any time of day and night. In the case of diagnostic application, it means that a long-term meteorological database which allows multi-year model simulations of pollutants, such as reactive nitrogen, is in existence, and is continuously updated. Detailed description of the model, its basic assumptions, configuration and capabilities are given in (Mazur 2008). In the next sections several applications of this model are presented.

\section{Nuclear pollution}

A classic example of an application of atmospheric dynamics forecasting models for pollution transport is the Chernobyl accident. At approximately 2:00 am on 26 April 1986, there was an explosion at the nuclear power plant at Chernobyl, Ukraine. This explosion destroyed the safety shields and the reactor building. At the same time, the first release of radioactive substances into the atmosphere occurred. Parts of the core (graphite and nuclear fuel) were scattered outside the reactor building. Shortly after this there was a second explosion of a mixture of hydrogen and air that had formed when hot steam reacted with the zirconium and graphite from the reactor's core. This explosion led to a fire in the reactor building and the machine

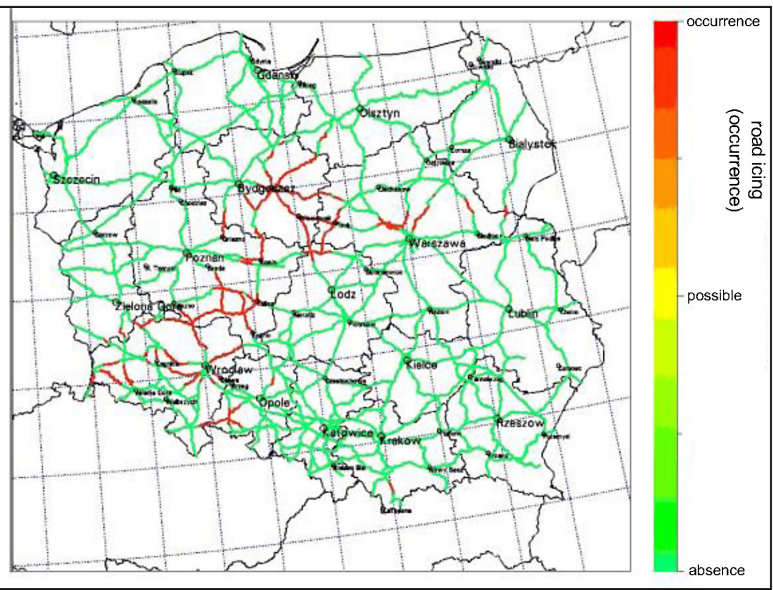

Fig. 4. An example of an operational forecast of visibility and road icing 


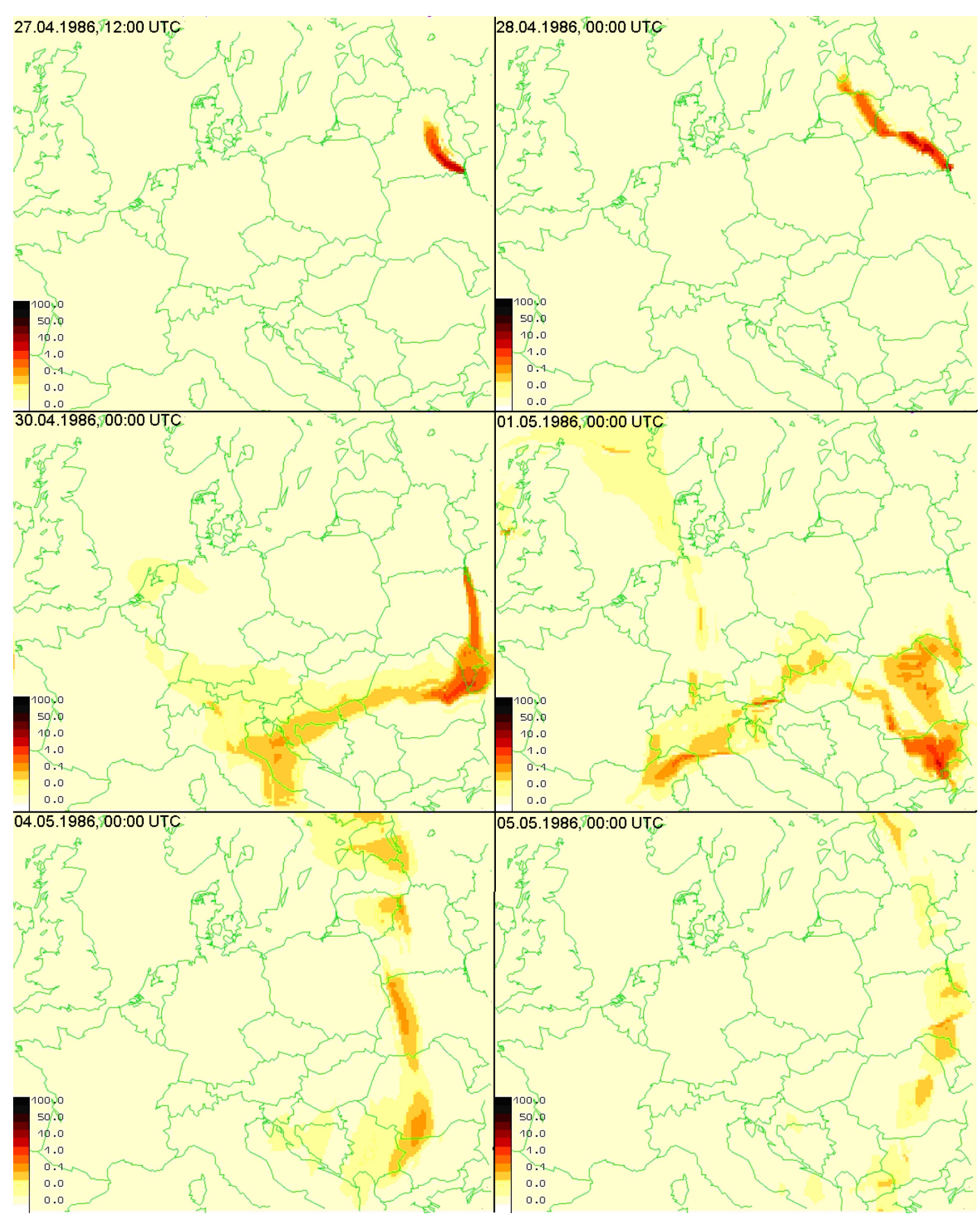

Fig. 5. Dispersion of the contamination cloud from the Chernobyl incident from 27.04.1986, 12:00 UTC to 05.05.1986, 00:00 UTC; intensity expressed in the percentage of maximum activity equal to $2.5 \mathrm{MBq} / \mathrm{m}^{3}$

room. The fire outside was extinguished in the morning of the same day. However, the remains of the core continued to burn inside the reactor building, causing a strong release of fission products into the atmosphere (Strupczewski 1987; Trojanowski et al. 2006). It has been assessed that about $4 \%$ of the nuclear fuel from the core entered the atmosphere, with about $20 \%$ of iodine radioactive isotope I $-121,13 \%$ of cesium- 137 and about $4 \%$ of strontium- 90 . The activity of the total emission of radioactive substances was at least $2 \cdot 10^{9} \mathrm{GBq}$. About $30 \%$ of the total release into the atmosphere occurred during the first day (OECD, NEA 1995). Using the available meteorological data ${ }^{1}$ at the time of the accident, a simulation of pollution transport (radioactive cloud evolution) was performed, starting on 27 April 1986 at 00:00 UTC and covering a period of 24 consecutive days (see Fig. 5).

Due to the meteorological situation over central Europe in April/May 1986, a cloud of radioactive contamination passed over Poland several times. A centre of high pressure remained over Poland and Belarus until 3 May 1986, causing pollution to drift over the central part of Europe. This effect was registered by stations detecting radioactive contamination and demonstrated afterwards,

${ }^{1}$ Meteorological (reanalysis) data for the simulation were obtained from the Data Support Section of the National Center for Atmospheric Research, Computational and Information Systems Laboratory, CISL, USA 


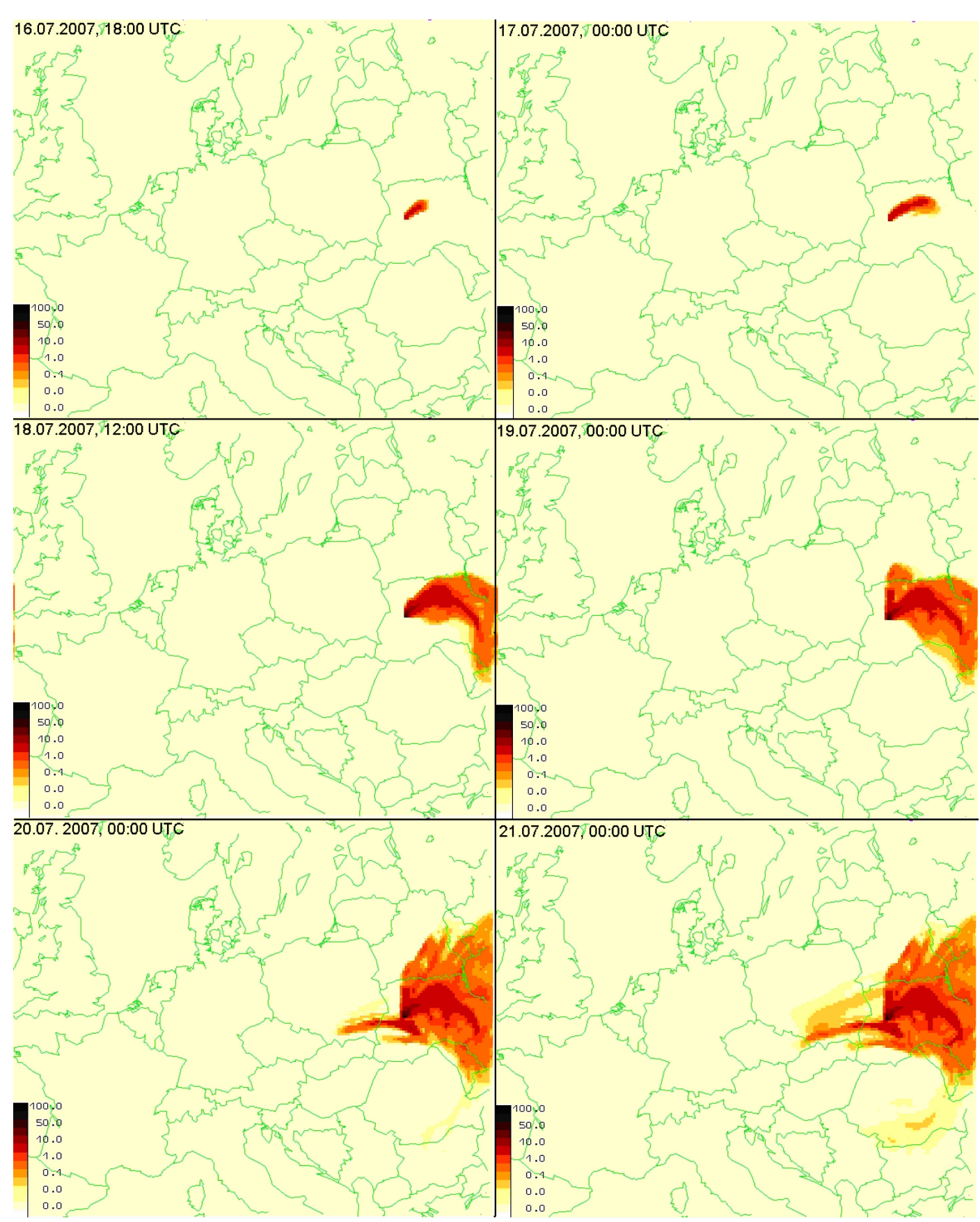

Fig. 6. Ozhidiv accident: dispersion of cloud of hazardous vapor from 16.07.2007, 18:00 UTC to 21.07.2007, 00:00 UTC; units correspond to percentage of maximum contaminant concentration $\left(5 \mathrm{mg} / \mathrm{m}^{3}\right)$

using model a posteriori simulations. It should be noted that in a real case (operational mode), it is much more important to determine the direction of transport of a radioactive cloud (the result of this simulation) than the accurate level of the concentration of contamination. This is because in a real emergency situation - In a particular accident causing emissions of harmful or hazardous pollutants to the air - the level (intensity) and the nature of these emissions can only be roughly estimated, and they can only be known with a significant level of uncertainty. In such cases, routine measurements are carried out in the vicinity of the selected receptor. Comparison of these measurements with the results of model calculations can later be used to describe the chemical and physical properties of the source, and for the subsequent significant improvement of the model.

\section{Chemical pollution}

On 16 July 2007, near the village of Ożydiw (Ozhidiv) in the Lviv region of Ukraine, a freight train, carrying highly toxic, so-called "yellow", phosphorus, derailed. Fifteen tanks came off the track, six of them burst into flames, and a cloud of hazardous vapor was released into the atmosphere. According to reports from the Ukrainian authorities, the toxic cloud spread over an area of about 90 square kilometers around the site of the accident. About 
900 people were evacuated from the immediate danger zone. There were about 11,000 people in the area adjacent to the accident site. Initial reports suggested the impact of the accident to have been as severe as in Chernobyl, but thankfully it turned out not to be such a nightmare scenario.

It was expected that after the fire was extinguished on 18 July 2007, the polluted air might flow into Polish territory, especially immediately after this date. In consultation with the National Headquarters of the State Fire Service (which is responsible for the security of the country with regard to protection against chemical contamination), IMWM simulated the dispersion of the contamination. Using the COSMO model operational meteorological forecast after processing the input data necessary for the calculation of the atmospheric transport, the cloud contamination was predicted for the period from 16 to 20 July 2007 (see Mazur et al. 2014a). It was assumed that approximately 50 tons of the products of phosphorus combustion (basically $\mathrm{P}_{4} \mathrm{O}_{10}$ phosphorus decaoxide and/ or ortho-phosphates $\mathrm{PO}_{4}^{-3}$ as an aerosol) might enter the atmosphere over a period of 48 hours after the accident. Using this assumption, one could adopt deposition rates similar to those of sulfate $\left(\mathrm{SO}_{4}^{-2}\right)$ - due to the physical similarity of the two compounds. According to the results of calculations, the maximum concentration in the epicenter of the disaster was about $5 \mathrm{mg} / \mathrm{m}^{3}$ and over Poland it was approximately $3 \mu \mathrm{g} / \mathrm{m}^{3}$. The time evolution of the pollutant cloud is shown in Fig. 6.
Hypothetical scenario of a nuclear accident in the vicinity of Poland

As a component of EWS for the case of a possible nuclear accident in the vicinity of Polish territory, a special software module was developed at IMWM-NRI allowing for the fast (preliminary) evaluation of the dominating dispersion directions of atmospheric pollution. The module generates a graphic display of meteorological conditions after an accident, including trajectories of air parcels flowing from an event location (these cover three consecutive days following an accident). The trajectories are colored in relation to the start of the parcel movement forecast: red corresponds to the day of the forecast generation, yellow and green to the second day of the forecast (shifted by 12 hours), and blue and black to the third and fourth days respectively. A user can interactively select an accident location, initial height of release and time horizon of forecast for subsequent analysis to be issued to relevant crisis management authorities. An example result is shown in Fig. 7.

\section{Conclusions}

There is a tendency for extreme weather events to be more frequent and intense. We must be aware of this fact and several preventive measures must be taken on the national scale. The problem of disasters, accidents and incidents related to environmental contamination and the threat to society (human communities) already has a long history (Basher 2006).

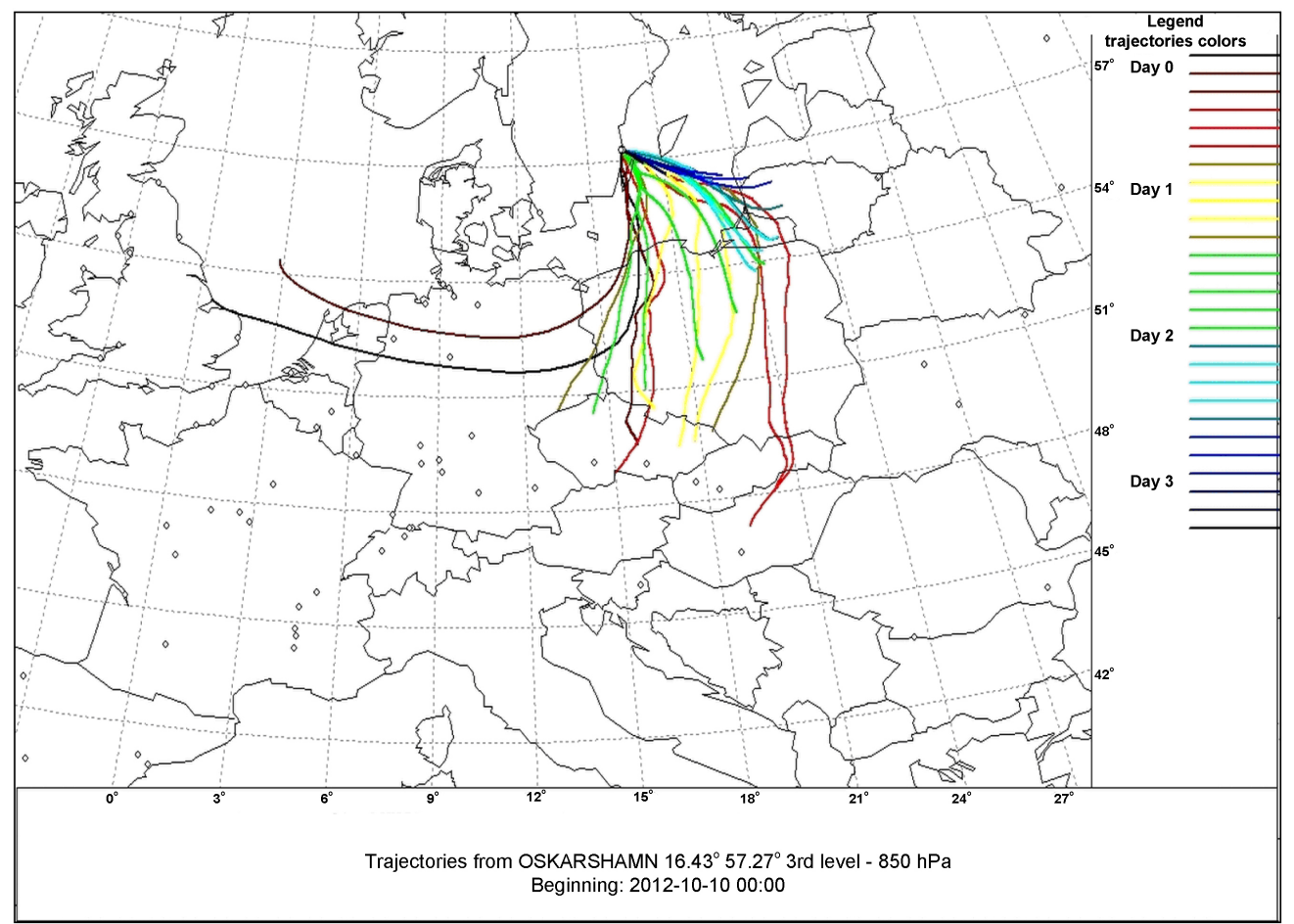

Fig. 7. Forecast trajectories of air parcels in the case of a hypothetical accident at the nuclear power plant in Oskarshamn, Sweden 
In general, there is a broad need for appropriate systems that correspond to crises in the fields of environmental hazards or human activities in general. These systems should be able to provide support and information about further developments, with a projected state of the environment and the possibility of the negative impact of various factors on the population (human communities) within this interaction covered in their scope. The ideal solution in future use would be an expansion of EWS to a more sophisticated Decision Support System (DSS, see e.g. Morton 1971 or Holsapple, Whinston 1996). Bearing in mind plans to build a nuclear power plant in Poland, there is an urgent need to prepare adequate tools that can help to avoid crisis situations, or at least to minimize their negative effects. The Early Warning System should be considered as one such tool, used not only for its economic benefits (e.g. energy or transport industries), but also for pro-social areas of services responsible for the appropriate reaction to crisis events. The design and implementation of the EWS is of major importance. Their introduction on various levels of administration is crucial for the minimization of the negative impact of extreme weather events, in both social and economic aspects. It should also be said that many EWS and/or DSS should work and provide appropriate results in a real time. This condition - in a certain way - reduces requirements for quality of results. From the point of view of decision-makers, as mentioned previously, it is more important to recognize whether, for example, a radioactive cloud will pass over a certain area than it is to know the actual concentration of contaminants in the cloud. Detailed analysis should be carried out subsequent to the very first moments of an accident, while urgent action should be taken immediately. Hence, a significant distinction between diagnosis and forecasting (or even nowcasting) should be considered in the practice of decision-making.

All systems mentioned above work operationally in IMWM-NRI. In general, atmospheric pollution transport forecast and the expert system for forecasters are dedicated to internal activities of National Weather Services (NWS) and serve as auxiliary tools in, for example, meteorological coverage of aviation or in the preparation of common forecasts and warnings. Conversely, SOMD is more targeted to actions beyond the scope of NWS and is designed for road maintenance services. However, both SOMD and REMOTA were tested carefully against real values (Mazur 2004a, 2008, 2011; Mazur et al. 2014) to estimate their validity for operational use.

Acknowledgments. This work was supported by the "Agreement between the Polish Ministry of the Environ- ment, the National Board of Water Management and the National Institute of Meteorology and Water Management - National Research Institute for the award of funding of the National Hydrological and Meteorological Service No. 43/DE/2013".

Abbreviations. EWS - Early Warning System, IMWMNRI - Institute of Meteorology and Water Management - National Research Institute, COSMO - Consortium for Small-Scale Modeling, (M)Bq- (mega) bequerels.

Bibliography

Basher R., 2006, Global early warning systems for natural hazards: systematic and people-centred, Royal Society of London Transactions Series A, 364 (1845), 2167-2182

Flerchinger G.M., Saxton K.E., 1995, The Simultaneous Heat and Water transfer model, Internal Report of Northwest Watershed Research Center, USDA Agricultural Research Service, Boise, Idaho

Holsapple C.W., Whinston A.B., 1996, Decision support systems: A Knowledge-Based Approach, West Group, 9060 pp.

Lowe D., Ebi K.L., Forsberg B., 2011, Heatwave early war-ning systems and adaptation advice to reduce human health consequences of heatwaves, International Journal of Environmental Research and Public Health, 8 (12), 4623-4648, DOI: 10.3390/ijerph8124623

Mazur A., 2004, Different types of applications of LM results simulations of dispersion of radioactive contamination, forecast for highways, Presentation at COSMO General Meeting, Milano, Italy

Mazur A., 2008, Unified model for atmospheric transport of pollutants over Poland, doctoral dissertation, IMGW, Warszawa

Mazur A., 2011, Meteorological forecasting for road services and authorities, Proceedings of $5^{\text {th }}$ Conference on Winter Road Maintenance

Mazur, A., Interewicz W., Linkowska J., Drzewiecki P., Lazanowicz M., Duniec G., 2012a, System analizy danych z modeli numerycznych oraz system asymilacji i analizy danych, Raport końcowy z wykonania zadania w projekcie badawczym pt. „Wpływ zmian klimatu na środowisko, gospodarkę i społeczeństwo", IMGW-PIB, Warszawa

Mazur A., Interewicz W., Linkowska J., Drzewiecki P., Lazanowicz M., Duniec G., 2012b, System analizy danych z modeli numerycznych oraz system asymilacji i analizy danych, [in:] Zmiany klimatu a monitoring i prognozowanie stanu środowiska atmosferycznego, M. Ziemiański, L. Ośródka (eds.), IMGW-PIB, Warszawa, 67-85

Mazur, A., Bartnicki, J. and Zwoździak, J., 2014, Modele transportu aerozoli atmosferycznych w ocenie środowiskowego zagrożenia, Medycyna Środowiskowa, 17 (1), 7-15 
Morton S., 1971, Management decision systems: ComputerBased support for decision making, PhD Thesis, Harvard University, Boston

OECD, NEA, 1995, Chernobyl. Ten years on. Radiological and health impact, OECD Nuclear Energy Agency, https://www. oecd-nea.org/rp/chernobyl/chernobyl-1995.pdf (access date: 09.01.2015)

Raatz W.E., 1995, Straßenzustands- und Wetterinformationssystem (SWIS), DWD Documents

Schaettler U., 2009, A Description of the Nonhydrostatic Regional COSMO-Model, Part V, Preprocessing: Initial and Boundary Data for the COSMO-Model, DWD documents

Schaettler U., Doms G., Schraff C., 2009, A Description of the Nonhydrostatic Regional COSMO-Model, Part VII, User Guide, DWD documents
Strupczewski A., 1987, Przyczyny i przebieg awarii w elektrowni jądrowej w Czarnobylu z reaktorem RBMK, Przegląd Elektrotechniczny, 8, 145-148

Trojanowski W., Dobrzyński L., Droste E., Strupczewski A., 2006, W 20-tą rocznicę awarii Czarnobylskiej elektrowni jądrowej, opracowanie Działu Szkolenia i Doradztwa Instytutu Problemów Jądrowych oraz Instytutu Energii Atomowej, http://ncbj.edu.pl/zasoby/awarie/20_rocznica_czarnobyla. pdf (access date: 09.01.2015)

Wantuch F., 2005, Visibility and fog forecasting based on the decision tree method, IDOJARAS, 105, 29-38 